\title{
A molecular chaperone inducer protects neurons from ER stress
}

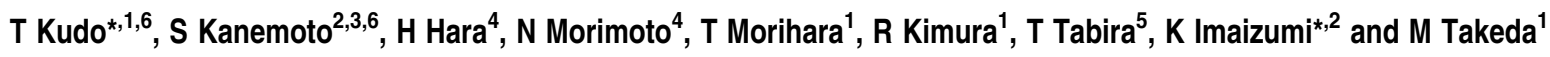

The endoplasmic reticulum (ER) stress response is a defense system for dealing with the accumulation of unfolded proteins in the ER lumen. Recent reports have shown that ER stress is involved in the pathology of some neurodegenerative diseases and cerebral ischemia. In a screen for compounds that induce the ER-mediated chaperone BiP (immunoglobulin heavy-chain binding protein)/GRP78 (78 kDa glucose-regulated protein), we identified BiP inducer X (BIX). BIX preferentially induced BiP with slight inductions of GRP94 (94 kDa glucose-regulated protein), calreticulin, and C/EBP homologous protein. The induction of BiP mRNA by BIX was mediated by activation of ER stress response elements upstream of the BiP gene, through the ATF6 (activating transcription factor 6) pathway. Pretreatment of neuroblastoma cells with BIX reduced cell death induced by ER stress. Intracerebroventricular pretreatment with BIX reduced the area of infarction due to focal cerebral ischemia in mice. In the penumbra of BIX-treated mice, ER stress-induced apoptosis was suppressed, leading to a reduction in the number of apoptotic cells. Considering these results together, it appears that BIX induces BiP to prevent neuronal death by ER stress, suggesting that it may be a potential therapeutic agent for cerebral diseases caused by ER stress.

Cell Death and Differentiation (2008) 15, 364-375; doi:10.1038/sj.cdd.4402276; published online 30 November 2007

The endoplasmic reticulum (ER) is an 'assembly plant' for the manufacture of secretory and membrane proteins. However, from time to time 'inferior goods', that is, unfolded/misfolded proteins in the ER are inevitable. Under normal physiological conditions, unfolded proteins are degraded; under conditions of ER stress, however, unfolded proteins can accumulate in the ER lumen. Eukaryotes utilize the unfolded protein response (UPR) to overcome the critical status induced by ER stress. ${ }^{1}$ The UPR consists of the following three pathways: (1) suppression of protein translation to prevent the generation of more unfolded proteins; (2) facilitation of refolding of unfolded proteins by the induction of ER chaperones; and (3) activation of ER-associated degradation (ERAD) to degrade the unfolded proteins accumulated in the ER, by the ubiquitinproteasome pathway. If these strategies are unsuccessful, cells go into ER stress-induced apoptosis.

Recent reports show that dysregulation of the UPR is implicated in much important pathology, including some neurodegenerative diseases and cerebral ischemia. Previously, the ER transducers inositol-requiring kinase 1 (IRE1), PKR(protein kinase regulated by RNA)-like ER-associated kinase (PERK), and activating transcription factor 6 (ATF6) were reported to be downregulated in presenilin-1 mutant neurons, causing the vulnerability to ER stress seen in cases of familial Alzheimer disease (AD) ${ }^{2-4}$ Caspase 4 , the human homologue of murine caspase 12 , was also reported to play a critical role in ER stress-induced neuronal cell death in AD. ${ }^{5}$ One inherited form of Parkinson's disease is associated with the accumulation of the protein Parkin-associated endothelin receptor-like receptor in the ER of dopaminergic neurons as a result of defective ERAD by mutant Parkin, a ubiquitin protein ligase (E3). ${ }^{6,7}$ Analysis of the polyglutamine tract associated with the spinocerebrocellular atrophy protein (spinocerebellar ataxia type 3) in Machado-Joseph disease suggests that cytoplasmic accumulation of this protein can inhibit proteasome function, thereby interfering with ERAD and eliciting ER stress-induced apoptosis. ${ }^{8,9}$ It was also reported that cerebral ischemia activates the UPR. ${ }^{10,11}$ These findings show that many cerebral disorders are related to an impaired UPR and ER stress-induced apoptosis.

These accumulated data concerning the involvement of $E R$ stress in cerebral disorders encouraged us to investigate this

\footnotetext{
${ }^{1}$ Psychiatry, Department of Integrated Medicine, Division of Internal Medicine, Osaka University Graduate School of Medicine, Suita, Japan; ${ }^{2}$ Division of Molecular and Cellular Biology, Department of Anatomy, Faculty of Medicine, University of Miyazaki, Miyazaki, Japan; ${ }^{3}$ Division of Structural Cellular Biology, Nara Institute of Science and Technology (NAIST) Graduate School of Biological Sciences, Ikoma, Japan; ${ }^{4}$ Department of Biofunctional Molecules, Gifu Pharmaceutical University, Gifu, Japan and ${ }^{5}$ National Institute for Longevity Science, Ohbu, Japan

*Corresponding authors: T Kudo, Psychiatry, Department of Integrated Medicine, Division of Internal Medicine, Osaka University Graduate School of Medicine, D3, 2-2, Yamadaoka, Suita 565-0871, Japan. Tel: + 8166879 3052; Fax: + 8166879 3059; E-mail: kudo @psy.med.osaka-u.ac.jp or

K Imaizumi, Division of Molecular and Cellular Biology, Department of Anatomy, Faculty of Medicine, University of Miyazaki, Kihara 5200, Kiyotake, Miyazaki 889-1692, Japan. Tel: + 8198585 1783; Fax: + 8198585 9851; E-mail: imaizumi@med.miyazaki-u.ac.jp

${ }^{6}$ These authors contributed equally to this work

Keywords: endoplasmic reticulum stress; chaperone; apoptosis; cerebral ischemia; neurodegeneration

Abbreviations: $\mathrm{AD}$, Alzheimer disease; ATF6, activating transcription factor 6; $\mathrm{BiP}$, immunoglobulin heavy-chain binding protein; $\mathrm{CHOP}, \mathrm{C} / \mathrm{EBP}$ homologous protein; EDEM, ER degradation-enhancing $\alpha$-mannosidase-like protein; elF2 $\alpha$, eukaryotic translation initiation factor 2 subunit $\alpha$; ERAD, ER-associated degradation; ERdj4/ MDG1, ER-localized DnaJ 4/microvascular differentiation gene 1; ERSE, ER stress response element; GRP78, 78 kDa glucose-regulated protein; GRP94, 94 kDa glucose-regulated protein; HSP70, 70 kDa heat-shock protein; IRE1, inositol-requiring kinase 1; MCA, middle cerebral artery; MEF, mouse embryonic fibroblast; PERK, PKR(protein kinase regulated by RNA)-like ER-associated kinase; p58 $8^{\mathrm{IFK}}$, protein kinase inhibitor of $58 \mathrm{kDa}$; Tg, thapsigargin; Tm, tunicamycin; TTC, 2,3,5triphenyltetrazolium chloride; UPR, unfolded protein response; XBP1, X-box binding protein 1

Received 02.1.07; revised 15.10.07; accepted 18.10.07; Edited by SH Kaufmann; published online 30.11.07
} 
field in an effort to identify therapeutic targets for the treatment of these disorders. We speculate that a therapeutic strategy that induces the UPR might prevent neuronal death induced by ER stress. According to the UPR pathway, we could try to (1) induce the expression of ER molecular chaperones; (2) block translation of proteins; or (3) artificially stimulate the degradation of misfolded proteins by the proteasome, as therapeutic approaches. Indeed, some chemical compounds that induce particular UPR pathways have been developed. For example, Boyce et al. ${ }^{12}$ identified salubrinal, a selective inhibitor of cellular complexes that dephosphorylates eukaryotic translation initiation factor 2 subunit $\alpha$ (elF2 $\alpha$ ), and thereby blocks translation. They concluded that salubrinal might be useful in the treatment of diseases involving ER stress. $^{12} \mathrm{Kim}$ et al. ${ }^{13}$ reported that valproate, a widely prescribed drug for epilepsy and bipolar disorder, increases the expression levels of the ER chaperones immunoglobulin heavy-chain binding protein (BiP), GRP94 (94 kDa glucoseregulated protein), protein disulfide isomerase, and calreticulin as well as the cytosolic chaperone HSP70 $(70 \mathrm{kDa}$ heat-shock protein). They also showed that valproate induces these chaperones without evoking the UPR, and speculated that inhibition of glycogen synthase kinase-3 by valproate might lead to the induction of chaperones. ${ }^{13}$

Previous reports have shown that induction of $\mathrm{BiP}$, an $\mathrm{ER}$ molecular chaperone, prevents neuronal death induced by ER stress. ${ }^{2,14-16}$ By contrast, inhibition of GRP78 (78 kDa glucose-regulated protein) mRNA induction increases cell death in response to calcium release from the $E R$, oxidative stress, hypoxia, and T-cell-mediated cytotoxicity. ${ }^{17-19}$ Therefore, in this paper, we searched for a chemical compound that induces $\mathrm{BiP}$ for possible use as a neuroprotective agent against ER stress. We have identified such a chemical compound, BiP inducer $\mathrm{X}(\mathrm{BIX})$, and shown its protective effect against ER stress-induced apoptosis in vivo and in vitro, suggesting that this compound might be useful in the treatment of cerebral disorders associated with ER stress, such as cerebral ischemia.

\section{Results}

BIX preferentially induces BiP. To identify chemical compounds that induce $\mathrm{BiP}$ mRNA, we utilized highthroughput screening (HTS) with a BiP reporter assay system. Of the screened compounds, 1-(3,4-dihydroxyphenyl)-2-thiocyanate-ethanone (Figure 1a) showed the highest level of induction of BiP mRNA; thus, we named this compound $\mathrm{BiP}$ inducer $\mathrm{X}(\mathrm{BIX})$.

First, we examined whether BIX does indeed induce the expression of BiP mRNA. Northern blot analysis and real-time PCR of SK-N-SH neuroblastoma cells treated with BIX showed that BIX induces BiP mRNA in a dose-dependent manner; however, the level of BiP mRNA induced by BIX is less than that induced by thapsigargin ( $\mathrm{Tg}$ ) (Figure $1 \mathrm{~b}$ ). Additionally, treatment of cells with $50 \mu \mathrm{M}$ BIX caused the highest induction of BiP and little toxicity to cells. Because BIX generated cytotoxicity at higher dosages, we did not use it at concentrations greater than $50 \mu \mathrm{M}$ in further analyses. Semiquantitative RT-PCR and real-time PCR showed that the
BiP signal peaked at $4 \mathrm{~h}$ after the addition of $5 \mu \mathrm{M}$ BIX and remained at that level until $6 \mathrm{~h}$ after treatment, with a subsequent reduction in level after this point (Figure 1c). To determine whether the induction of BiP mRNA by BIX results in an increase in the level of BiP protein, we carried out immunoblot analysis. As shown in Figure 1d, the level of BiP protein was increased by $5 \mu \mathrm{M}$ BIX in a time-dependent manner, consistent with the changes in mRNA levels.

Next, we performed semiquantitative RT-PCR analysis to investigate whether BIX affects the expression of any other ER stress response-related genes, such as GRP94, calreticulin, X-box binding protein 1 (XBP1), ER-localized DnaJ 4/microvascular differentiation gene 1 (ERdj4/MDG1), ER degradation-enhancing $\alpha$-mannosidase-like protein (EDEM), protein kinase inhibitor of $58 \mathrm{kDa}\left(\mathrm{p} 58^{\mathrm{IPK}}\right), \mathrm{C} / \mathrm{EBP}$ homologous protein (CHOP), and asparagine synthetase (ASNS) (Figure 2a). According to the time-course study of BiP induction by $\mathrm{BIX}$ (Figure 1c), a $6 \mathrm{~h}$ treatment of cells with $\mathrm{BIX}$ was adopted into this study. XBP1 mRNA, which is spliced under ER stress induced by $1 \mu \mathrm{M}$ Tg or $1 \mu \mathrm{g} / \mathrm{ml}$ tunicamycin (Tm), was not processed in cells treated with $5 \mu \mathrm{M}$ BIX. Compared with a control sample, ERdj4/MDG1, EDEM, p58 ${ }^{\mathrm{IPK}}$, and ASNS were scarcely induced by BIX. On the other hand, GRP94, calreticulin, and CHOP were induced by BIX, but their inductions were not as prominent as that of $\mathrm{BiP}$. We also performed time-course analyses on the expressions of ER stress response-related genes by real-time PCR in SK-N-SH cells treated with $50 \mu \mathrm{M}$ BIX as well as $5 \mu \mathrm{M}$ BIX. A $5 \mu \mathrm{M}$ portion of BIX induced GRP94, calreticulin, and CHOP mRNA as well as BiP. However, BiP was definitely induced from 2 to $6 \mathrm{~h}$ (Figure $2 \mathrm{~b}$ ). The time courses for EDEM,

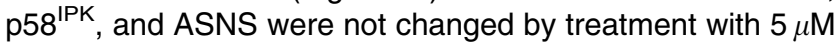
$\mathrm{BIX}$ (Figure 2b). A $50 \mu \mathrm{M}$ portion of BIX also induced BiP from 4 to $6 \mathrm{~h}$ and transiently induced calreticulin and CHOP. Even $50 \mu \mathrm{M} \mathrm{BIX}$ did not induce EDEM, p58 ${ }^{\mathrm{IPK}}$, or ASNS (Figure 2b).

Moreover, we performed immunoblot analysis of GRP94 and phosphorylated elF $2 \alpha$ to examine whether BIX affects other signaling pathways that participate in the ER stress response. Treatment of SK-N-SH cells with BIX caused very slight induction of GRP94 protein compared with its induction by $1 \mu \mathrm{M} \mathrm{Tg}$ (Figure $2 \mathrm{c}$ ). This result was consistent with that of semiquantitative RT-PCR analysis of the GRP94 mRNA level. Treatment of cells with $1 \mu \mathrm{M} \mathrm{Tg}$ increased the level of phosphorylated elF2 $\alpha$, but BIX did not cause its phosphorylation (Figure 2c). These results indicate that BIX invokes little ER stress, but almost preferentially induces BiP.

The induction of BiP by $\mathrm{BIX}$ is mediated by activation of ERSEs through the ATF6 pathway. To investigate the mechanism by which BiP is induced by $\mathrm{BIX}$, we performed reporter assays using $132 \mathrm{bp} \mathrm{BiP-pGL3} \mathrm{reporter} \mathrm{plasmids} \mathrm{as}$ described in the Materials and Methods section. A BiP (132)pGL3 plasmid (Figure 3a) was transfected into SK-N-SH

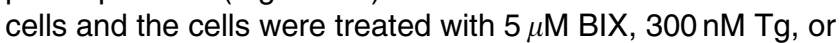
$0.5 \mu \mathrm{g} / \mathrm{ml} \mathrm{Tm}$ for either 6 or $16 \mathrm{~h}$. The reporter activities in transfectants were elevated in response to stimulation with $\mathrm{Tg}$ or $\mathrm{Tm}$, and maintained at a long-lasting high level (Figure 3b). By contrast, reporter activities in cells treated with BIX were transiently induced at $6 \mathrm{~h}$ after stimulation and then downregulated to basal levels by $16 \mathrm{~h}$ (Figure $3 \mathrm{~b}$ ). This 
<smiles>N#CSCC(=O)c1ccc(O)c(O)c1</smiles>

b
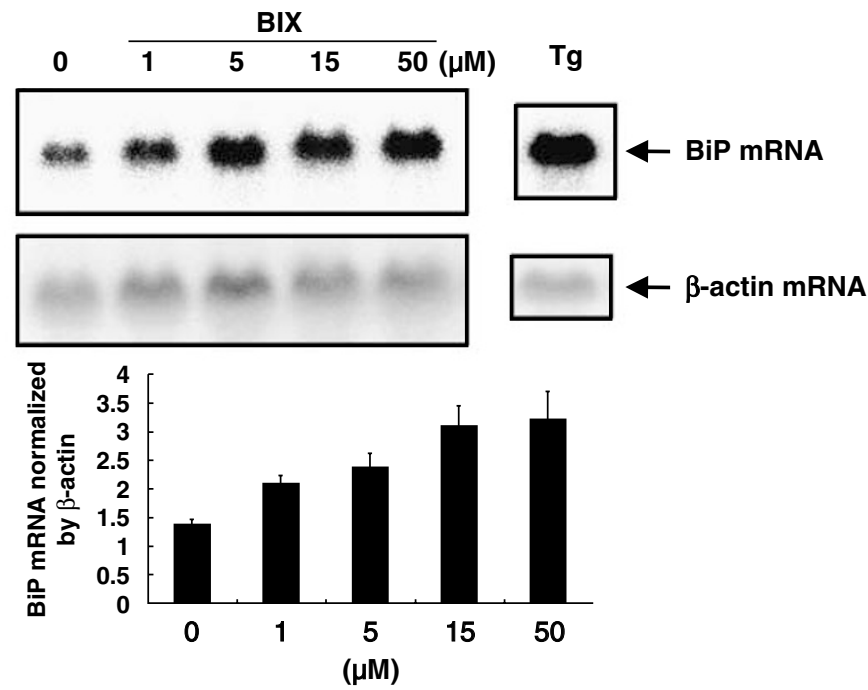

d
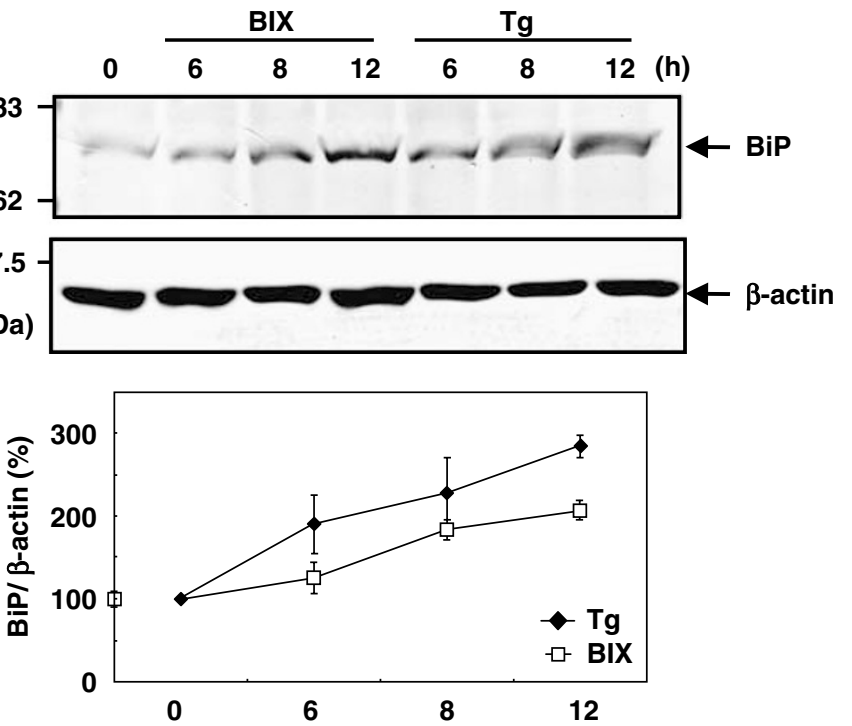

(h)

Figure 1 BIX induces BiP. (a) The structure of BIX (1-(3,4-dihydroxyphenyl)-2-thiocyanate-ethanone). (b) Dose-dependent induction of BiP mRNA in SK-N-SH cells after $6 \mathrm{~h}$ of treatment with BIX is shown by northern blot (upper panel) and real-time PCR (lower panel); values are means \pm S.D. from three independent experiments. The induction of BiP mRNA by Tg is shown as a positive control. $\beta$-Actin mRNA is shown as an internal control. (c) The time course of BiP mRNA induction in cells treated with BIX is shown by semiquantitative RT-PCR (upper panel) and real-time PCR (lower panel); values are means \pm S.D. from three independent experiments. The level of BiP mRNA peaked in $4 \mathrm{~h}$ and kept until $6 \mathrm{~h}$ after treatment with BIX at $5 \mu \mathrm{M}$, with a subsequent reduction after this point. (d) A time-dependent induction of BiP protein in SK-N-SH cells treated with $5 \mu \mathrm{M} \mathrm{BIX}$ or $1 \mu \mathrm{M} \mathrm{Tg}$ is detected by immunoblot and quantified by densitometry. Values are means \pm S.D. from three independent experiments

finding supports the results shown in Figure 1c and suggests that the effects of $\mathrm{BIX}$ on $\mathrm{BiP}$ induction are transient and that $\mathrm{BiP}$ mRNA reverts to basal levels. Therefore, induction of $\mathrm{BiP}$ by BIX might be caused by a mechanism different to that used by ER stressors such as Tg and Tm, and the BIXresponsive element(s) might be included in the $132 \mathrm{bp} \mathrm{BiP}$ promoter region. Within this $132 \mathrm{bp}$ region, there are three ER stress response elements (ERSEs) (Figure 3a). Subsequently, we carried out the reporter assay using an ERSE mut (132)-pGL3 plasmid (Figure 3a) to confirm whether or not these ERSEs are involved in the induction of $\mathrm{BiP}$ by BIX. BiP (132)-pGL3 or ERSE mut (132)-pGL3 was transfected into SK-N-SH cells, and the cells were treated with $5 \mu \mathrm{M}$ BIX for $6 \mathrm{~h}$. The reporter activities in cells transfected with BiP (132)-pGL3 were increased $\sim 4$-fold by $\mathrm{BIX}$. On the other hand, induction of reporter activity was not observed in cells transfected with ERSE mut (132)-pGL3 (Figure $3 c$ ). This result suggests that ERSEs are involved in the induction of BiP by BIX.

Next, to examine whether three major transducers of the ER stress response, namely PERK, IRE1, and ATF6, affect the induction of $\mathrm{BiP}$ by $\mathrm{BIX}$, we analyzed the expression of $\mathrm{BiP}$ in knockout/knockdown mouse embryonic fibroblasts (MEFs) lacking each transducer (Figure 3d). In PERK-deficient MEFs and IRE $1 \alpha / \beta$ double-knockout MEFs, BiP mRNA was induced by $\mathrm{BIX}$ to a similar level to that seen in wild-type cells 
a

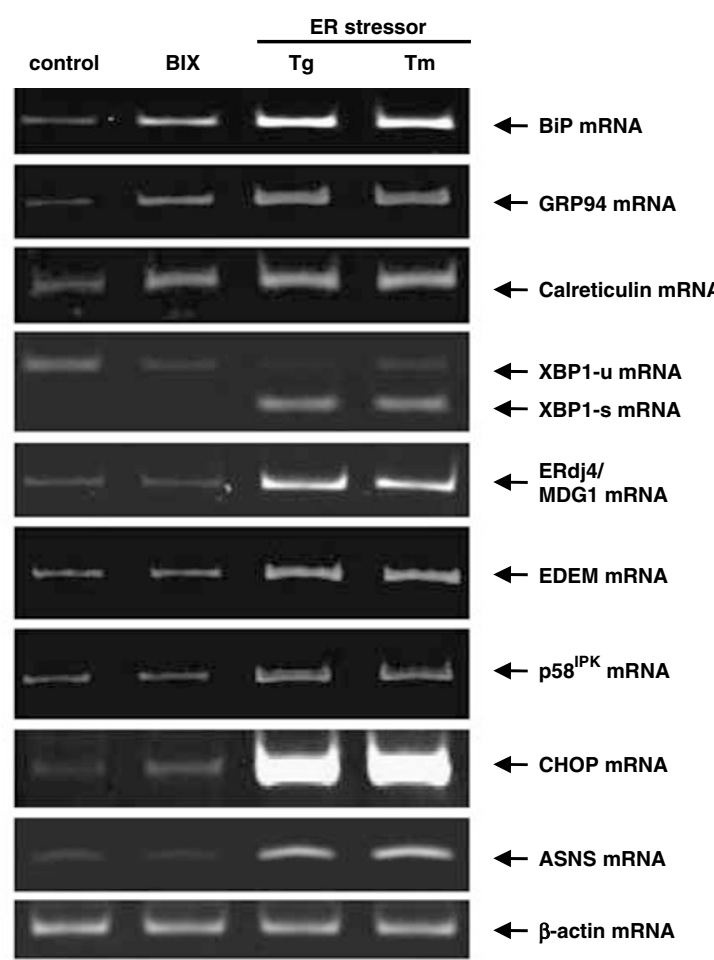

b
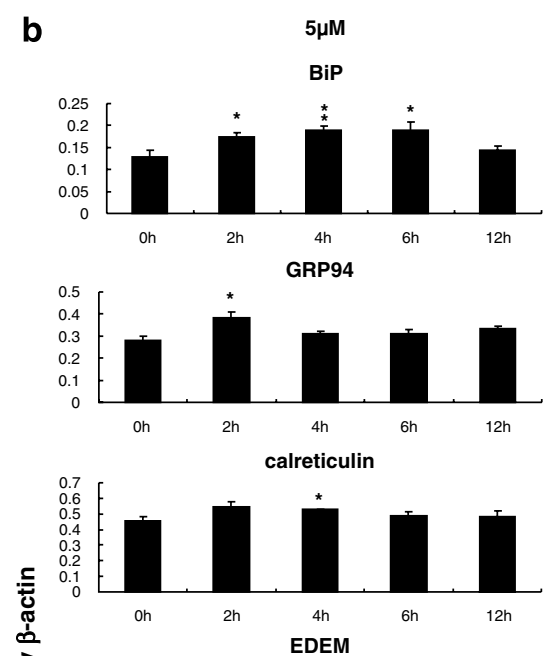

EDEM

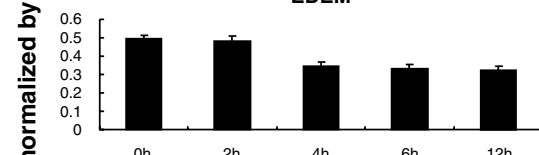

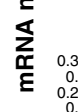

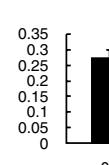

p5 $8^{\text {IPX }}$

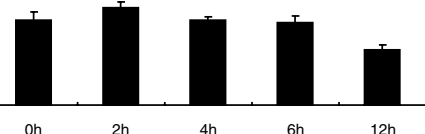

CHOP

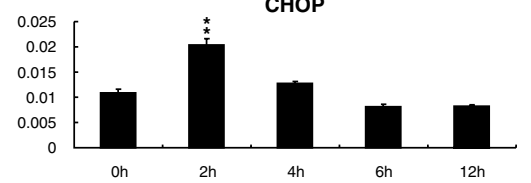

ASNS

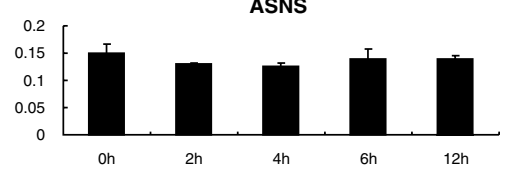

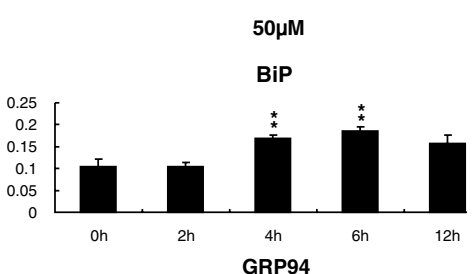
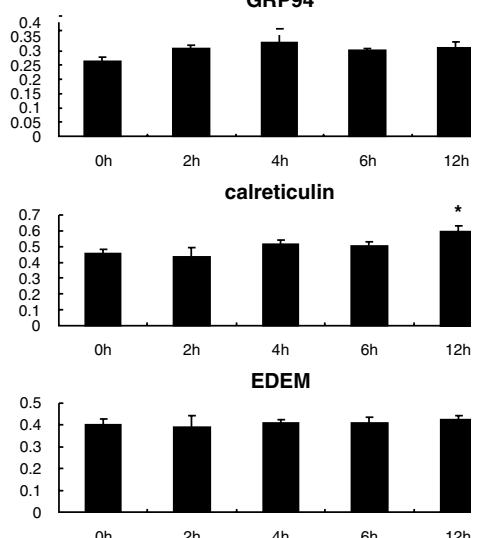

p58 $8^{\mathrm{IPK}}$
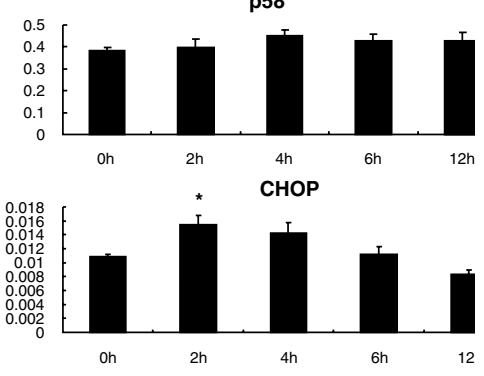

ASNS

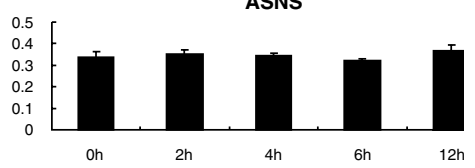

Figure 2 BIX preferentially induces BiP. (a) Semiquantitative RT-PCR analysis shows that a $6 \mathrm{~h}$ treatment of cells with $5 \mu$ M BIX induces BiP mRNA but not spliced XBP1 (XBP1-s), ERdj4/MDG1, EDEM, p58 IPK, and ASNS mRNAs, which are induced by $1 \mu \mathrm{M} \mathrm{Tg}$ or $1 \mu \mathrm{g} / \mathrm{ml} \mathrm{Tm}$. GRP94, calreticulin, CHOP are slightly induced by BIX. (b) Time-course analyses by real-time PCR show that $5 \mu \mathrm{M}$ BIX significantly induces BiP from 2 to $6 \mathrm{~h}$ after BIX administration and transiently induces GRP94, calreticulin, and CHOP. The mRNAs of EDEM, p58 , and ASNS are not changed from 2 to $12 \mathrm{~h}$. A $50 \mu \mathrm{M}$ portion of BIX also induces BiP from 4 to $6 \mathrm{~h}$ and transiently induces calreticulin and CHOP. Even $50 \mu \mathrm{M}$ BIX does not induce EDEM, p58 ${ }^{\mathrm{PRK}}$, and ASNS. Values are means $\pm \mathrm{S}$. E. from $3-4$ independent experiments. Significant differences are based on the values at $0 \mathrm{~h},{ }^{*} P<0.05$, ${ }^{\star *} P<0.01$. (c) Immunoblot analysis with quantification shows that $5 \mu \mathrm{M}$ BIX causes very slight induction of GRP94 protein but does not induce the phosphorylation of elF2 $\alpha$ at any time point, compared with $1 \mu \mathrm{M}$ Tg. Values are means \pm S.D. from three independent experiments 

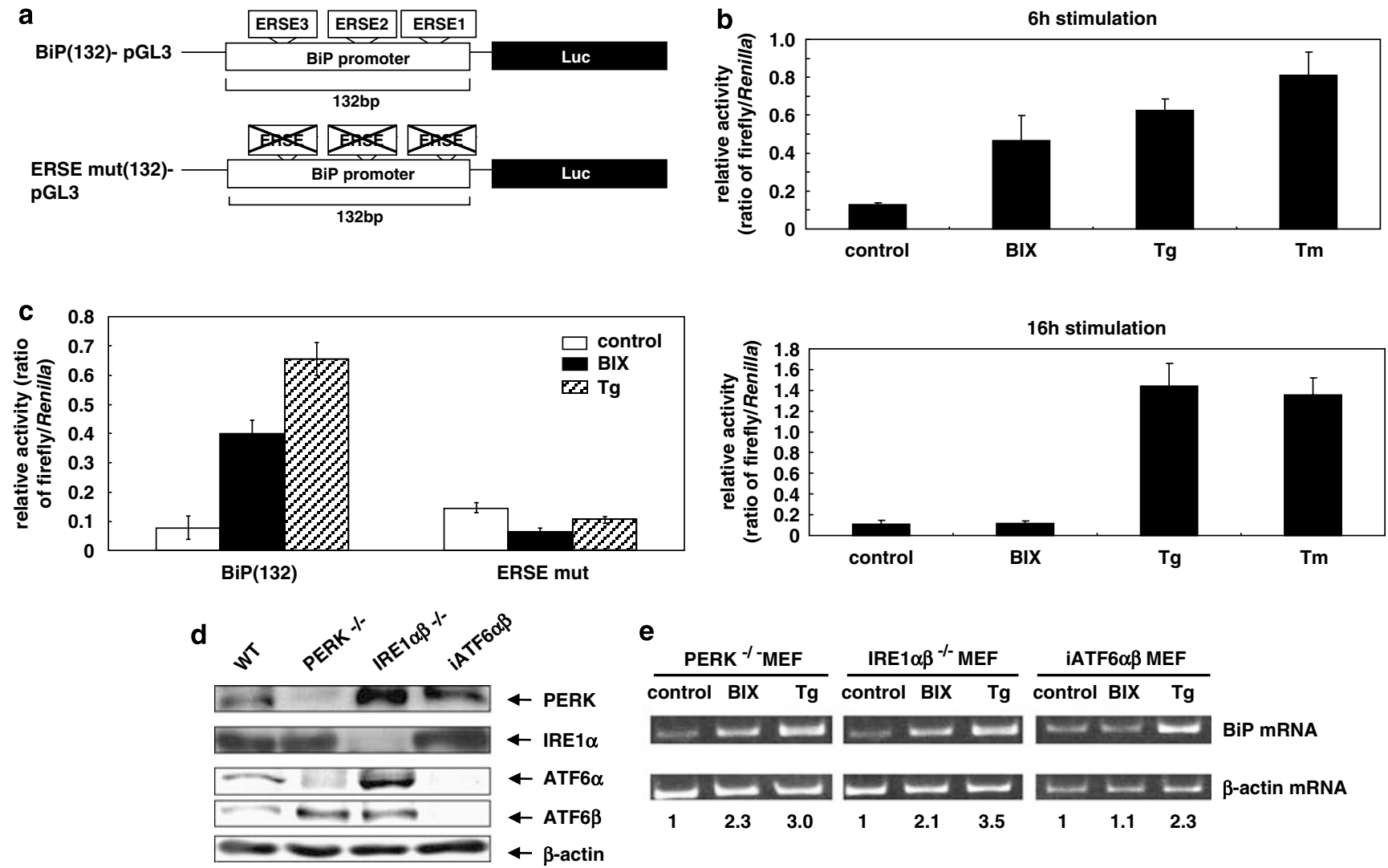

e

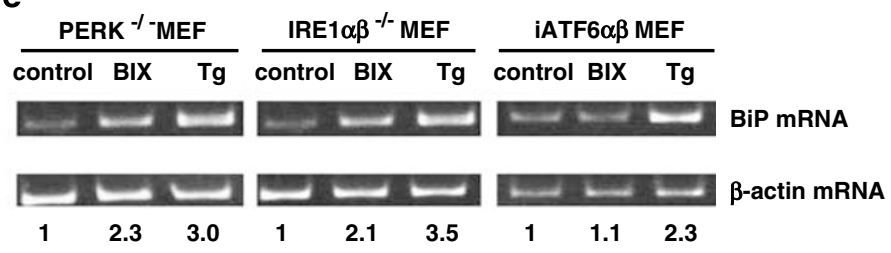

Figure 3 The induction of BiP by BIX is mediated by ERSE and the ATF6 pathway. (a) Schematic representation of the BiP promoter cloned into the pGL3 plasmid (BiP (132)-pGL3) and the ERSE mutant BiP promoter cloned into the pGL3 plasmid (ERSE mut (132)-pGL3). (b) The luciferase activities driven by the BiP promoter are normalized against Renilla luciferase activities. The induction of luciferase activity in BiP (132)-pGL3-transfected cells that are treated with $5 \mu \mathrm{M}$ BIX increased at $6 \mathrm{~h}$ after BIX treatment and reversed to basal levels by $16 \mathrm{~h}$. Induction of luciferase activity in $300 \mathrm{nM} \mathrm{Tg}$ - or $0.5 \mu \mathrm{g} / \mathrm{ml} \mathrm{Tm}$-treated cells is sustained until $16 \mathrm{~h}$ after BIX treatment. Values are means \pm S.D. from five independent experiments. (c) The relative reporter activity in cells transfected with BiP (132)-pGL3 (ratio of firefly/Renilla) at $6 \mathrm{~h}$ after treatment in cells treated with BIX $(5 \mu \mathrm{M})$ are increased $\sim 4$-fold, whereas that in cells transfected with ERSE mut (132)-pGL3 are not increased. Values are means \pm S.D. from five independent experiments. $\mathrm{Tg}(300 \mathrm{nM})$ also increases reporter activity in cells transfected with BiP (132)-pGL3, but not in cells transfected with mut (132)-pGL3. (d) Immunoblot analyses of PERK ${ }^{-1-}$ MEFs, IRE $1 \alpha \beta^{-1-}$ MEFs, and iATF6 $\alpha \beta$ (knockdown) MEFs with anti-PERK, anti-IRE 1 and anti-ATF6 $\alpha / \beta$ antibodies prove the deficiency of those genes. (e) Semiquantitative RT-PCR analysis shows that BiP mRNA is induced at $6 \mathrm{~h}$ after treatment with BIX $(50 \mu \mathrm{M})$ in PERK ${ }^{-1-}$ MEFs and IRE $\alpha \beta^{-l-}$ MEFs, but not in iATF6 $\alpha \beta$ (knockdown) MEFs. Tg induces BiP mRNA in all three MEFs. Numeric values below the panels indicate the induction ratio of BiP mRNA adjusted to the level of $\beta$-actin mRNA with reference to non-treated control sample as one

(Figure 3e). These results indicate that the induction of BiP by $\mathrm{BIX}$ is not mediated via the PERK or IRE1 pathways. The data showing that elF2 $\alpha$ is not phosphorylated by BIX (Figure 2c), and that XBP1 is not processed by BIX (Figure 2a), support this conclusion. By contrast, BiP was not induced by BIX in ATF6 $\alpha \beta$ double-knockdown MEFs (Figure 3e), suggesting that BIX treatment mediates the induction of BiP via the ATF6 pathway. These results were also obtained by northern blot analysis (data not shown). The data showing that BIX induced GRP94, calreticulin, and CHOP, and that ERdj4/MDG1, EDEM, $p 58^{\mathrm{IPK}}$ and ASNS were not induced by BIX (Figure $2 a, b)$, also suggested that the effect of BIX is mediated by the ATF6 pathway. This is because the inductions of GRP94, calreticulin, and CHOP are known to be dependent on the activation of ATF6; inductions of ERdj4/MDG1, EDEM, p58 ${ }^{\text {IPK }}$ are known to be mediated by IRE1 and that of ASNS by PERK. Next, we tried to detect the cleavage of ATF6 in cells treated with BIX, but we have not yet detected cleaved $\mathrm{N}$-terminal fragments of endogenous ATF6 using the antibody described in this study (data not shown).
BIX protects SK-N-SH cells from ER stress-induced apoptosis. BiP functions as a cytoprotective protein in stressed cells. ${ }^{14-16}$ As BIX activates BiP expression, BIX might protect cells from ER stress. To investigate whether $\mathrm{BIX}$ has the ability to prevent apoptosis induced by ER stress, SK-N-SH cells were pretreated for $12 \mathrm{~h}$ with 0 or $5 \mu \mathrm{M}$ $\mathrm{BIX}$, which was then replaced with fresh medium containing $0.5 \mu \mathrm{g} / \mathrm{ml} \mathrm{Tm}$. Phase-contrast images (Figure $4 \mathrm{a}-\mathrm{d}$ ) and fluorescence micrographs (Figure $4 \mathrm{e}-\mathrm{h}$ ) of Hoechst staining show that apoptotic cell death was observed within $36 \mathrm{~h}$ of Tm treatment (Figure $4 \mathrm{~d}, \mathrm{~h}$ ), and that the number of dead cells had increased significantly (Figure 4i). By contrast, cell death was significantly inhibited by pretreatment with BIX (Figure 4c, g, i). We also found that treatment of cells with BIX only for $36 \mathrm{~h}$ caused no changes in cells (Figure $4 \mathrm{~b}, \mathrm{f}$ ). Next, we looked at the activation of caspases 4 and $3 / 7$ after ER stress. Caspase 4 was reported to be activated in response to ER stress in human cells. ${ }^{5}$ Immunoblot analysis showed that pretreatment of cells with BIX attenuated the cleavage of caspase 4 (Figure 4j). Moreover, we analyzed 

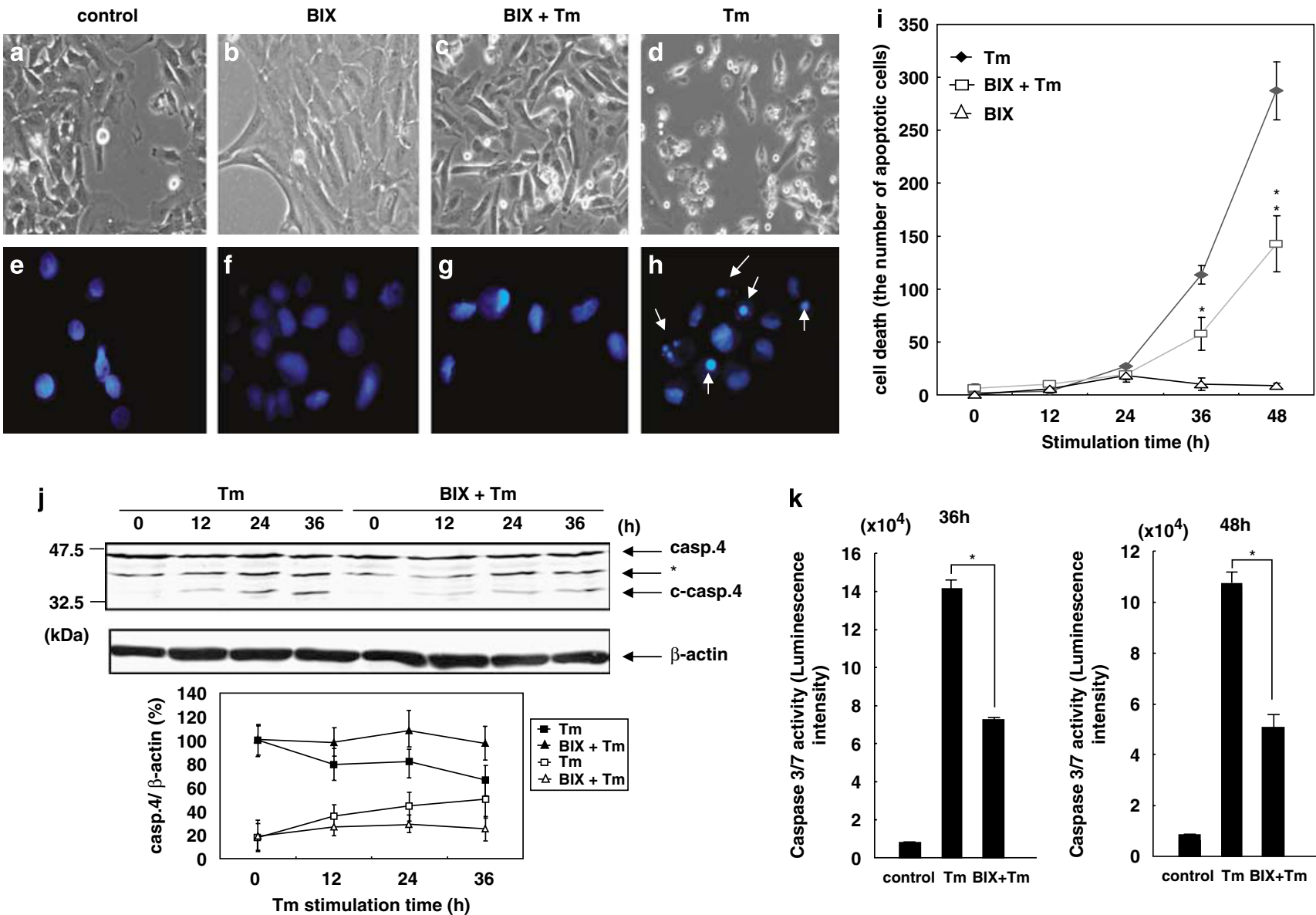

Figure 4 BIX protects SK-N-SH cells from ER stress-induced apoptosis. SK-N-SH cells are pretreated with vehicle (control: $\mathbf{a}, \mathbf{e}$; Tm: $\mathbf{d}, \mathbf{h})$ or with $5 \mu \mathrm{M}$ BIX (BIX: $\mathbf{b}, \mathbf{f}$; $\mathrm{BIX}+\mathrm{Tm}: \mathbf{c}, \mathbf{g})$ for $12 \mathrm{~h}$, and then the whole medium is replaced with fresh medium (control, BIX) or medium supplemented with $0.5 \mu \mathrm{g} / \mathrm{ml} \mathrm{Tm}(\mathrm{BIX}+\mathrm{Tm}, \mathrm{Tm})$. Phasecontrast images (a-d) and fluorescence micrographs of Hoechst staining $(\mathbf{e}-\mathbf{h})$ at $36 \mathrm{~h}$ after Tm stimulation show that pretreatment of cells with BIX reduces the number of Tminduced apoptotic cells. Arrows show apoptotic cells (h). (i) The number of dead cells (apoptotic cells) after Tm treatment increases from 0 to $48 \mathrm{~h}$. Pretreatment of cells with BIX significantly reduces the amount of cell death compared with cells treated with $\operatorname{Tm}$ only ( ${ }^{\star} P<0.05,{ }^{* \star} P<0.01$ ). BIX alone does not cause remarkable cell death. A total of 500 cells are counted at each time point. Values are means \pm S.D. from five independent experiments. (j) Immunoblot of caspase 4 shows that Tm causes cleavage of caspase 4 (c-Casp.4) in a time-dependent manner and that pretreatment of cells with BIX attenuates this cleavage with no change in the level of $\beta$-actin. Asterisk indicates nonspecific bands. The lower panel shows quantitative analyses of full-length and cleaved caspase 4. Filled square and triangle indicate full-length caspase 4; open square and triangle indicate cleaved caspase 4. Values are means \pm S.D. from three independent experiments. (k) The caspases 3 and 7 activities in Tm-treated cells are increased. $\mathrm{BIX}$ reduces this caspase activity to almost half value of the Tm-treated levels. Values are means \pm S.D. from three independent experiments; ${ }^{*} P<0.01$

the activities of caspases 3 and 7 . The activities of caspases 3 and 7 in Tm-treated cells were extremely high. By contrast, $\mathrm{BIX}$ reduced the activities of caspases 3 and 7 to half of those in cells treated with $\mathrm{Tm}$ only (Figure 4k). Taken together, these findings suggest that pretreatment of cells with BIX inhibits cell death induced by ER stress involving inhibited activation of caspases $3 / 7$ and 4 .

BIX administration reduces the insults due to cerebral infarction. Because it has been shown that cerebral ischemia causes ER stress, ${ }^{20}$ we performed occlusions of the middle cerebral arteries (MCAs) of mice to confirm whether the protective effects of BIX in vitro can be utilized in vivo. Immunoblot analysis of extracts from the cerebral hemisphere showed that $20 \mu \mathrm{g}(2 \mu \mathrm{l})$ of BIX (administered intracerebroventricularly) significantly increased the level of BiP protein $24 \mathrm{~h}$ after administration, confirming that administration of $\mathrm{BIX}$ induces $\mathrm{BiP}$ protein in vivo
(Figure 5a). Real-time PCR analysis of the expression of ER stress response-related genes showed that $20 \mu \mathrm{g}$ BIX significantly induced $\mathrm{BiP}$ at $6 \mathrm{~h}$ after administration (Figure 5b). The levels of GRP94, calreticulin, and $\mathrm{CHOP}$ mRNA also increased; however, those of EDEM, p58 ${ }^{\mathrm{PPK}}$, and ASNS did not change (Figure $5 b$ ), consistent with the results of in vitro study (Figure 2b). Animals treated with BIX showed no behavioral changes, except for the neurological deficits induced by ischemia. Neurological evaluation at $24 \mathrm{~h}$ after MCA occlusion showed that most of the vehicle-administered (control) mice presented with moderate symptoms; for example, circling to the contralateral side (Figure $5 \mathrm{c}$ ). By contrast, most BIX-administered (5 or $20 \mu \mathrm{g}$ ) mice presented with milder symptoms; for example, extending the right forepaw (Figure $5 c$ ).

Twenty-four hours after occlusion, 2,3,5-triphenyltetrazolium chloride (TTC) staining showed that the mice had developed infarcts affecting the ipsilateral cortex and striatum 


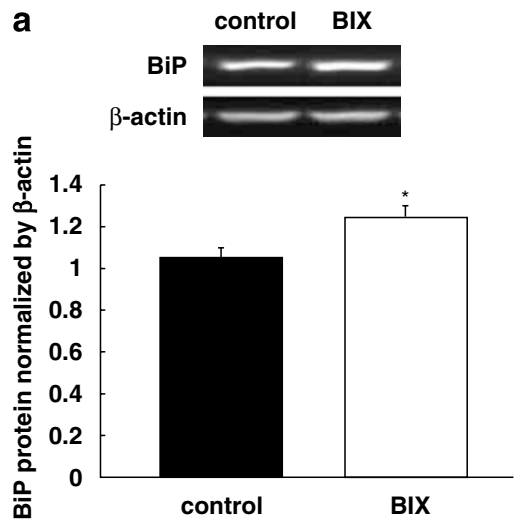

b
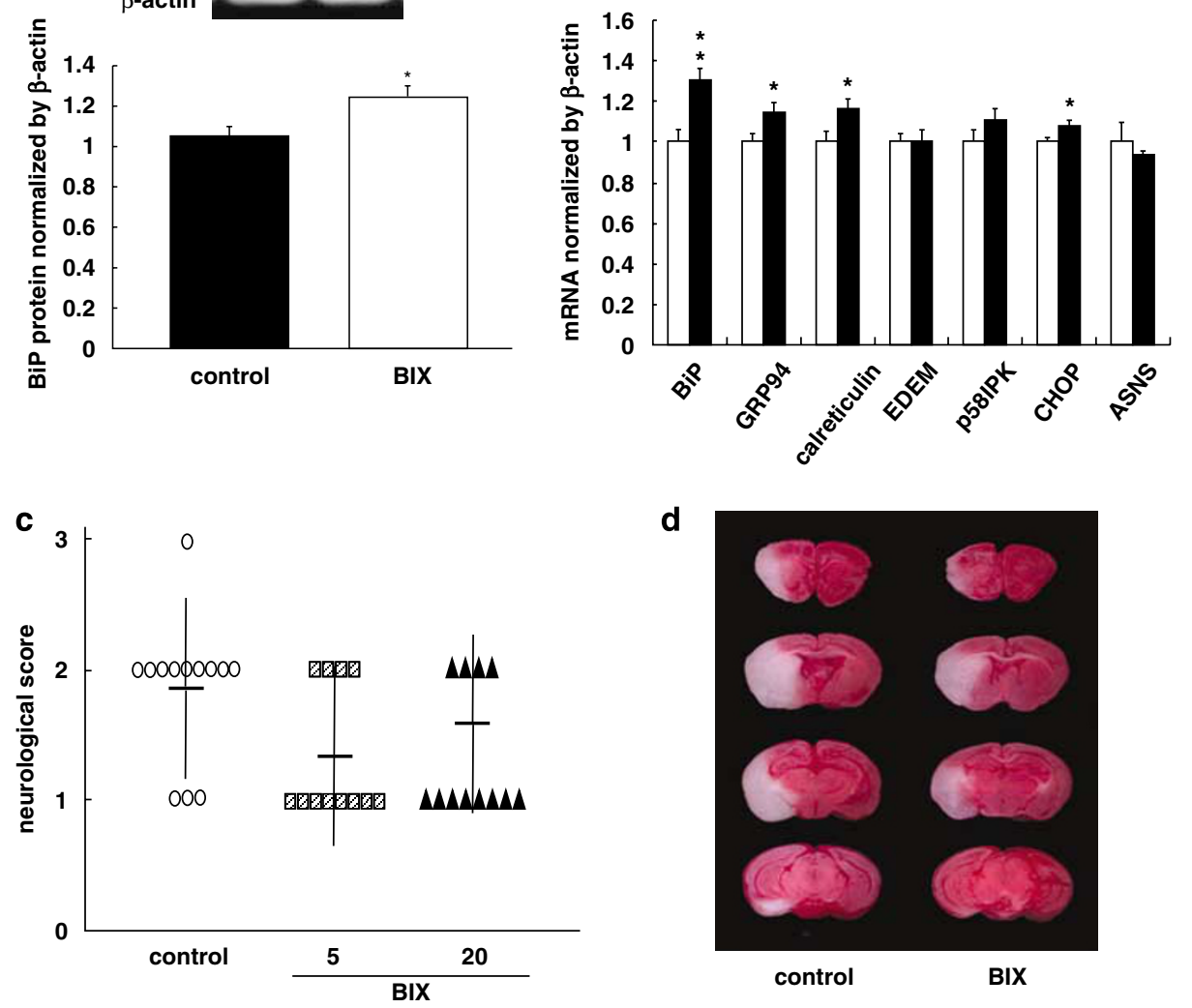

d
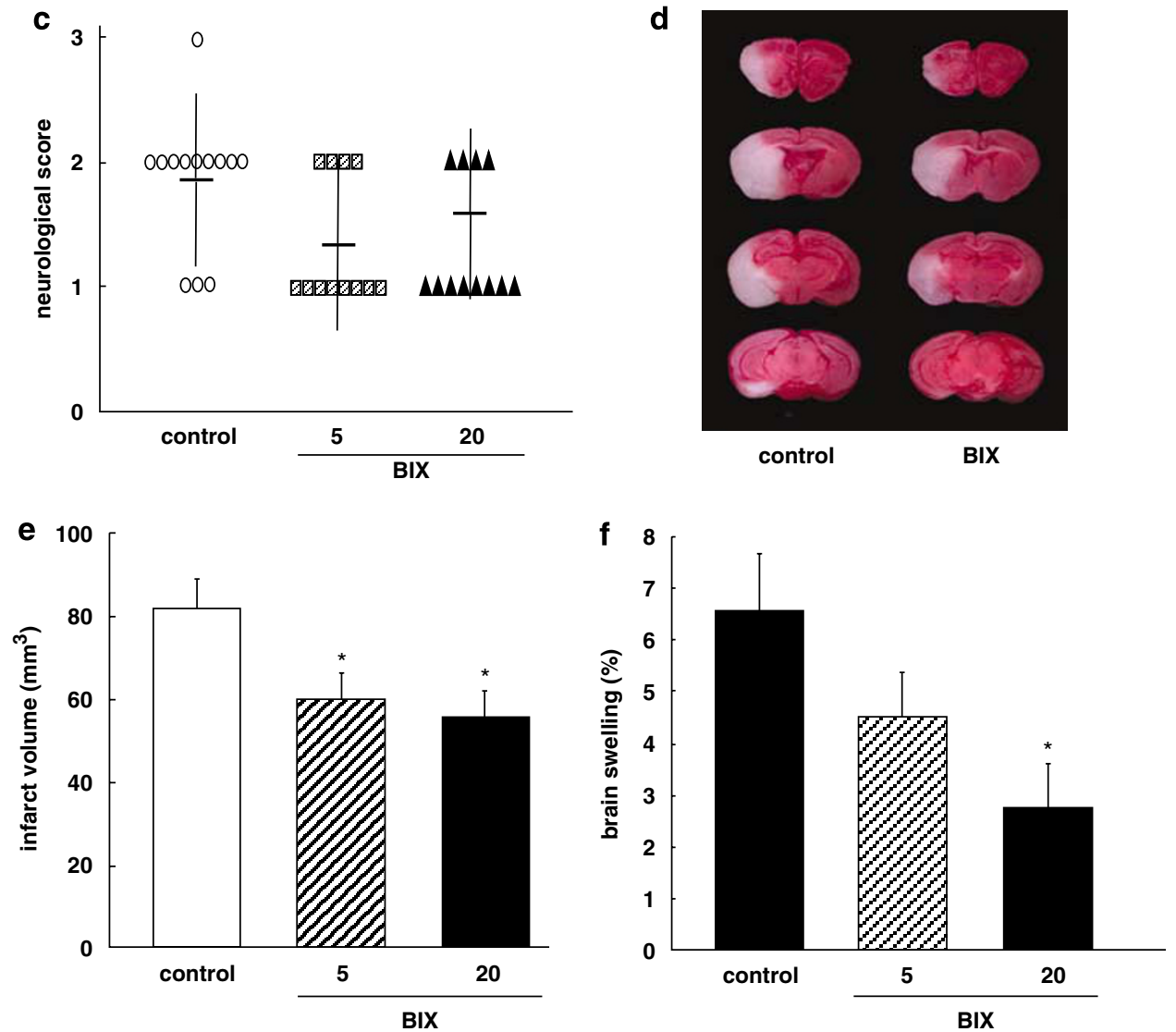

Figure $5 \mathrm{BIX}$ administration reduces the extent of cerebral infarction after MCA occlusion. (a) It is confirmed that intracerebroventricular administration of BIX raises the level of BiP protein in mouse brains. Immunoblot analysis of BiP and $\beta$-actin protein in BIX-administered $(20 \mu \mathrm{g} / 2 \mu \mathrm{l})$ brains shows that the level of BiP protein is significantly increased at $24 \mathrm{~h}$ after BIX administration compared with vehicle-treated brains. The inset is the representative immunoblot detected by luminescence of ECL. Densitometric scanning of BiP bands normalized to $\beta$-actin was performed. Data are represented as means \pm S.E. from four independent experiments; ${ }^{*} P<0.05$. (b) The real-time PCR shows that the level of BiP (in arbitrary units) in the BIX-administered $(20 \mu \mathrm{g} / 2 \mu \mathrm{l})$ hemisphere is increased significantly at $6 \mathrm{~h}$ after administration. The levels of GRP94, calreticulin, and CHOP mRNA are increased by BIX; the levels of EDEM, p58 ${ }^{\mathrm{IPK}}$, and ASNS do not change. The black bar is the BIX-administered $(20 \mu \mathrm{g} / 2 \mu \mathrm{l})$ hemisphere; the white bar is the vehicle-administered hemisphere. Values are means \pm S.E. from 3-4 independent experiments; ${ }^{*} P<0.05,{ }^{* *} P<0.01$. (c) Neurological deficits at $24 \mathrm{~h}$ after occlusion of the MCA are scored using the following scale: $0=$ no observable neurological deficits (normal); 1 = failure to extend the right forepaw (mild); $2=$ circling to the contralateral side (moderate); $3=$ loss of walking or righting reflex (severe). BIX administration ( 5 or $20 \mu \mathrm{g}$ ) improves neurological deficits induced by MCA occlusion. Values are means (horizontal bold bar) \pm S.D. (d) Representative images of TTC staining at $24 \mathrm{~h}$ after MCA occlusion. Note that the infarct area (white or pink) in BIX-administered brains is smaller than that in brains treated with vehicle. (e) Quantitative analysis of infarct volumes measured by TTC staining. Values are means \pm S.E. from 12 or 13 independent experiments; ${ }^{*} P<0.05$. (f) BIX administration (5 or $20 \mu \mathrm{g}$ ) reduces brain swelling induced by MCA occlusion. Values are means \pm S.E. from 12 or 13 independent experiments; ${ }^{*} P<0.05$ 
(Figure 5d). The core of infarction was observed as a white area and the penumbra was pink. The infarction area (core + penumbra) observed in BIX-treated brains was smaller than that in vehicle-treated brains (Figure $5 d$ ). Quantitation of TTC staining showed that administration of 5 or $20 \mu \mathrm{g}$ of $\mathrm{BIX}$ significantly reduced the infarction area (Figure 5e). Furthermore, measurement of brain swelling also showed that administration of $20 \mu \mathrm{g}$ of $\mathrm{BIX}$ significantly reduced brain swelling after $24 \mathrm{~h}$ of ischemia (Figure $5 \mathrm{f}$ ).

BIX administration reduces apoptosis induced in the penumbra by MCA occlusion. Detailed observation of TTC-stained ischemic brains indicated that the reduction in the area of infarction in BIX-treated brains was predominantly due to a reduction in the area of the penumbra rather than the core. Therefore, we examined the penumbra of BIX-treated brain for evidence of apoptosis. Terminal deoxynucleotidyl transferase-mediated dUTP-biotin nick end labeling (TUNEL) staining of ischemic brains without BIX treatment revealed an increased number of TUNEL-positive cells in the ipsilateral core and penumbra compared with the contralateral side (Figure 6a). By contrast, the number of TUNEL-positive cells was significantly reduced in the ipsilateral penumbra of BIX-treated brains compared with that of vehicle-treated brains (Figure 6a, b). Immunohistochemistry for caspase 3 in the penumbrae of BIX-and vehicle-treated brains showed that $\mathrm{BIX}$ reduced the number of apoptotic cells at $24 \mathrm{~h}$ after MCA occlusion (Figure 6c, d). CHOP plays a role in apoptotic cell death by ER stress. ${ }^{21}$ Moreover, it is well-known that $\mathrm{CHOP}$ is induced after ischemic insults. ${ }^{22}$ Therefore, we examined the effects of $\mathrm{BIX}$ treatment on the induction of CHOP mRNA after ischemia. In situ hybridization analysis showed that $\mathrm{CHOP}$ mRNA was significantly induced in the penumbra of MCA-occluded mice, whereas pretreatment of mice with $\mathrm{BIX}$ resulted in a marked reduction in the level of CHOP mRNA expression (Figure 6e, f). Although $\mathrm{BIX}$ induced $\mathrm{CHOP}$ (Figure $5 \mathrm{~b}$ ), the extent of this induction was very weak compared with the expression induced by ischemia (Figure $6 e, f$ ). The results of TUNEL staining and in situ hybridization for CHOP indicate that BIX suppresses the ER stress-mediated apoptotic cell death induced in the penumbra after ischemia.

\section{Discussion}

If a BiP inducer is just an ER stressor such as $\mathrm{Tg}$ or $\mathrm{Tm}$, its application as a therapeutic strategy is unlikely to be realized because it may activate several pathways of the UPR, including ER stress-induced apoptotic pathways. The present studies in knockout or knockdown MEFs deficient in ER stress sensors showed that the ATF6 pathway is necessary for BIX to induce $\mathrm{BiP}$. This is consistent with the evidence that BIX preferentially induced BiP with slight inductions of GRP94, calreticulin, and CHOP mediated by the ATF6 pathway, and that BIX does not affect the pathway downstream of IRE1 or the translational control branch downstream of PERK. Moreover, for the apoptotic branches of ER stress, the transient induction of $\mathrm{CHOP}$ by BIX was very weak compared with the severe induction observed in ER stress, and caspase 4 was not activated by BIX. The differences among inductions between $\mathrm{BiP}$ and the other genes of the ATF6 pathway by BIX suggested that elements other than ERSEs may be involved in the induction of BiP by BIX.

The present data from in vitro studies showed that BIX suppresses the cleavage of caspase 4, a member of one of the apoptotic pathways mediated by ER stress. Because it was reported that PERK is activated after cerebral ischemia ${ }^{10}$ and that XBP1 mRNA splicing is detected after transient cerebral ischemia, ${ }^{11}$ it would appear that cerebral ischemia causes ER stress. Thus, to examine the antiapoptotic effect of $\mathrm{BIX}$ in vivo, we used MCA-occluded mice. Intracerebroventricular pretreatment of mice with BIX reduced the area of infarction in the brain, especially the area of the penumbra. BIX pretreatment also reduced the severity of neurological deficits caused by focal cerebral ischemia. In the penumbrae of BIX-treated brains, the induction of CHOP, an apoptotic molecule induced by ER stress, was suppressed, suggesting that $\mathrm{BIX}$ reduces cell death by preventing ER stress-induced apoptosis. As the infarct volumes, brain swelling, and neurological scores following 5 and $20 \mu \mathrm{g}$ treatments were similar, $5 \mu \mathrm{g}$ of $\mathrm{BIX}$ might be sufficient to protect against ischemia. This is the first report demonstrating the in vivo success of a therapeutic manipulation to inhibit apoptosis mediated by ER stress, indicting that BIX might be a potential therapeutic for neuroprotection after cerebral infarction.

The induction of BiP by BIX was transient, peaking at $4 \mathrm{~h}$ after treatment, but the levels of BiP protein continued to increase until $12 \mathrm{~h}$. The reporter assay using the $132 \mathrm{bp}$ BiP-pGL3 plasmid also showed that the effect of BIX on the induction of $\mathrm{BiP}$ was transient and weaker than the effect of ER stressors, such as Tg or Tm. Even a high dosage of BIX $(50 \mu \mathrm{M})$ did not induce genes mediated by non-ATF6 pathways. These results imply that the mechanism of BiP induction utilized by BIX may be different from those used by these ER stressors. It was reported that the activation of transducers of ER stress is caused by dissociation of BiP from their luminal domains. ${ }^{23}$ It may be assumed that artificial induction of BiP disturbs the activation of transducers of ER stress, because abundant $\mathrm{BiP}$ remains bound to these transducers preventing their activation. However, the effect of BIX peaked at $4 \mathrm{~h}$ and remained at that level until $6 \mathrm{~h}$ after treatment; after this point, there was a subsequent reduction in level. Therefore, the production of BiP induced by BIX may not disturb this dissociation.

An earlier study showed that a selective inhibitor of elF2 $\alpha$ dephosphorylation protects cells from ER stress ${ }^{12}$ and that the development of novel chemical compounds for diseases related to ER stress is underway. It is possible that $\mathrm{BIX}$, which has effects in vivo, could have therapeutic applications in the treatment of diseases involving ER stress. We propose that $\mathrm{BiP}$ activators, such as BIX, will be effective agents against ER stress. However, further studies will be required to investigate the pharmacology of BIX, including its possible side effects, before BiP activators can be used in clinical practice.

\section{Materials and Methods}

Cell culture. SK-N-SH neuroblastoma cells were grown in $\alpha$-modified Eagle's medium supplemented with $10 \%$ fetal bovine serum. MEFs derived from IRE1 ${ }^{-1}$ embryos or PERK ${ }^{-1}$ embryos were cultured in Dulbecco's modified Eagle's 


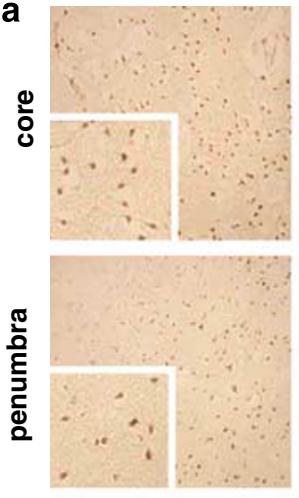

control
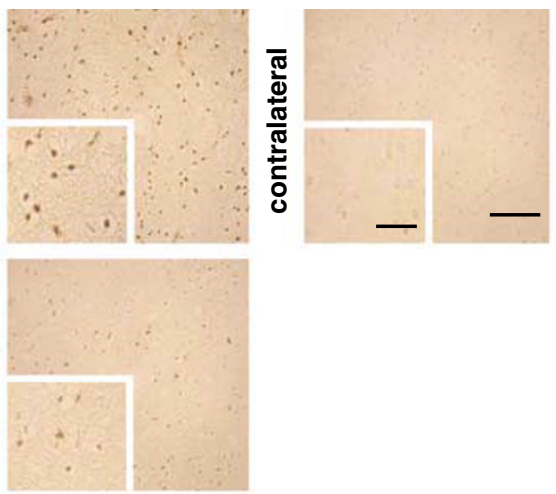

BIX b (cells $\left./ \mathrm{mm}^{2}\right)$

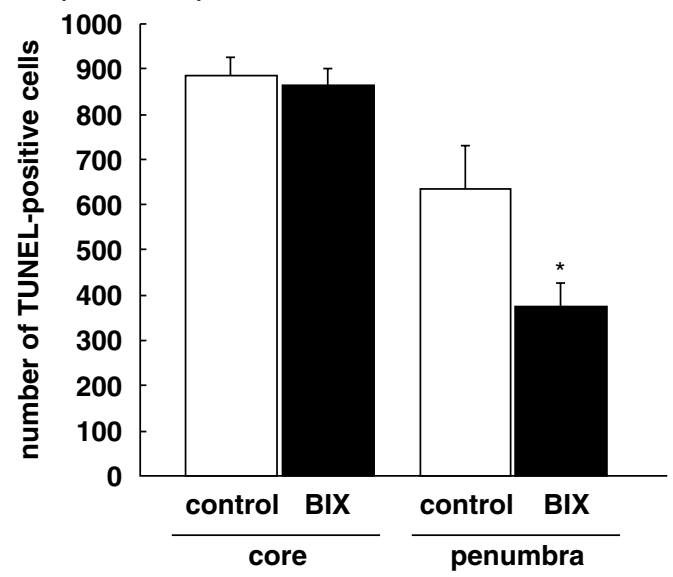

A
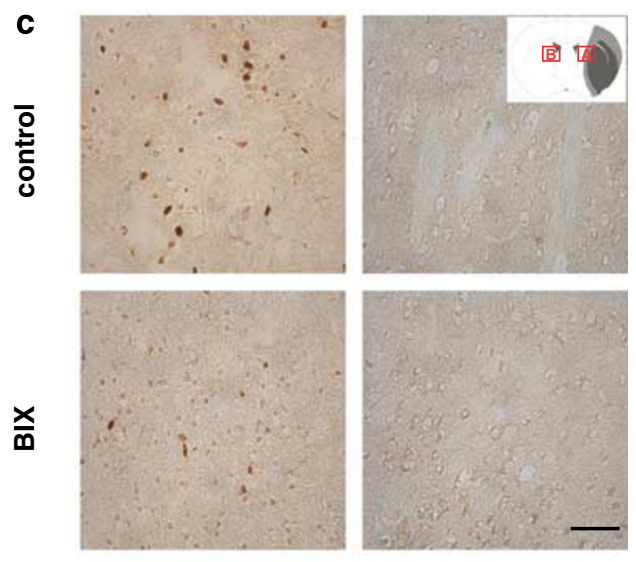

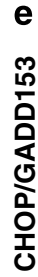
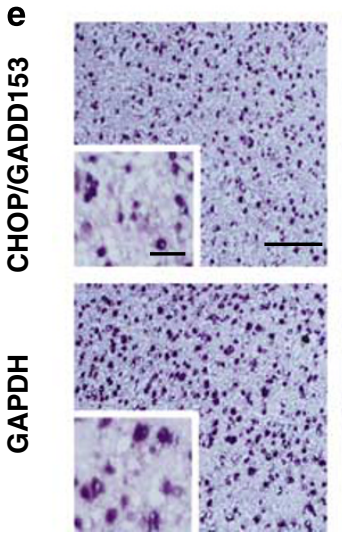

control
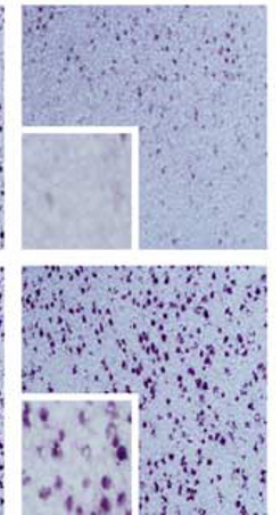

BIX

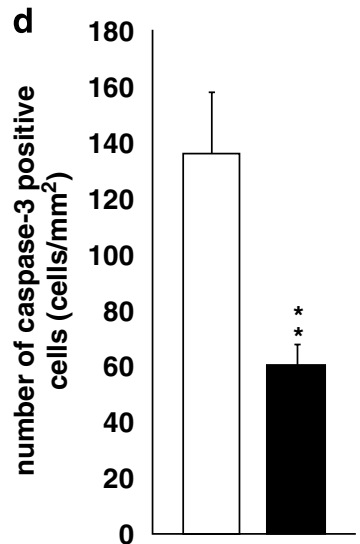

control BIX

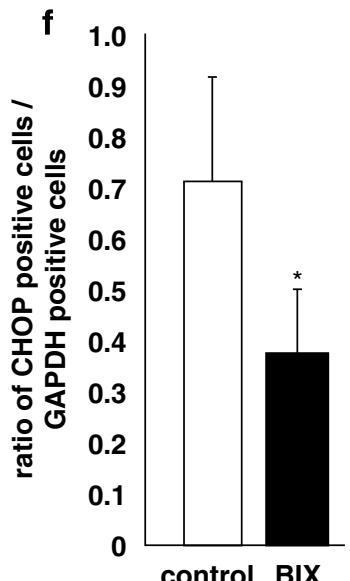

Figure 6 A $20 \mu \mathrm{g}$ portion of BIX administration reduces ER stress-induced apoptosis induced in the penumbra by MCA occlusion. (a) Representative images of TUNEL staining in the core, penumbra, or contralateral side to the infarction at $24 \mathrm{~h}$. Insets are higher magnification images. BIX administration reduces the number of TUNEL-positive cells induced in the penumbra by MCA occlusion. Scale bar for higher magnification panels, $10 \mu \mathrm{m}$; lower magnification panels, $100 \mu \mathrm{m}$. (b) Cell-counting analysis shows that BIX significantly reduced the number of TUNEL-positive cells in the penumbra. Values are means \pm S.D. from 9 or 10 independent experiments; ${ }^{*} P<0.05$. (c) Representative image showing immunohistochemical staining for caspase 3 in the penumbra area $(\mathbf{A})$ and contralateral area $(\mathbf{B})$ in a BIX-treated mouse and vehicle-treated mouse at $24 \mathrm{~h}$ after treatment. Scale bar, $50 \mu \mathrm{m}$. (d) Quantitative analysis of caspase 3-positive cells. Values shown are the number of caspase 3-positive cells $/ \mathrm{mm}^{2}$. Values are means \pm S.D. from five independent experiments; ${ }^{* *} P<0.01$. (e) Representative images of in situ hybridization for $C H O P$, an apoptotic molecule induced in penumbra by ER stress at $24 \mathrm{~h}$. Insets are higher magnification images. Scale bar for higher magnification panels, $10 \mu \mathrm{m}$; lower magnification panels, $100 \mu \mathrm{m}$. (f) Quantitative analysis of CHOP-positive cells. Values shown are the ratios of $\mathrm{CHOP}-/ \mathrm{GAPDH}$-positive cells. Values are means \pm S.D. from five independent experiments; ${ }^{*} P<0.05$ 
medium supplemented with $10 \%$ fetal bovine serum. MEFs in which both ATF6 $\alpha$ and ATF6 $\beta$ (iATF6 $\alpha \beta$ MEF) had been knocked down were also maintained in the Dulbecco's modified Eagle's medium. PERK ${ }^{-1-}$ MEFs, IRE $1^{-1-}$ MEFs, and iATF6 $\alpha \beta$ MEFs were kindly provided by Drs. David Ron (New York University, NY USA), Dr. Fumihiko Urano (University of Massachusetts Medical School, MA, USA), and Laurie H Glimcher (Harvard School of Public Health, MA, USA), respectively.

Reagents. Cells were treated with $\mathrm{Tm}$ or $\mathrm{Tg}$ to induce ER stress conditions. Tm was purchased from Sigma (St. Louis, MO, USA). Tg was purchased from Alomone Labs Ltd (Jerusalem, Israel). Hoechst staining was performed according to the manufacturer's instructions.

Plasmids. A pGL3-BiP promoter (132)-Luc reporter plasmid (BiP (132)-pGL3) and an ERSE mutant BiP promoter-Luc reporter plasmid (ERSE mut (132)-pGL3) were provided by Dr. K Mori (Kyoto University, Kyoto, Japan).

Transfection and reporter assays. SK-N-SH cells were grown to $80 \%$ confluence and then transfected using Lipofectamine 2000 reagent, according to the manufacturer's instructions (Invitrogen, Carlsbad, CA, USA). Cells were transfected with a reporter plasmid $(0.2 \mu \mathrm{g})$ carrying the firefly luciferase gene under the control of the BiP promoter, and a reference plasmid pRL-SV40 $(0.02 \mu \mathrm{g})$ carrying the Renilla luciferase gene under the control of the SV40 enhancer and promoter (Promega, Madison, WI, USA). At $12 \mathrm{~h}$ after transfection, cells were treated with library compounds to screen for compounds that induce BiP. Firefly and Renilla luciferase activities were measured in $10 \mu \mathrm{l}$ of cell lysate using a DualLuciferase Reporter Assay System (Promega) and a luminometer (Berthold Technologies, Bad Wildbad, Germany). Relative luciferase activity was defined as the ratio of firefly luciferase activity to Renilla luciferase activity. Values were averaged from quadruplicate determinations. Using these BiP reporter cells, HTS was performed on a compound library consisting of approximately 10000 compounds. The molecules were synthesized based on the structures of 10 lead compounds that had high activity in HTS. Among the synthesized molecules, we chose a small molecule that had the highest activity, naming it BIX. To confirm the induction of BiP by this compound, $5 \mu \mathrm{M} \mathrm{BIX}, 300 \mathrm{nM} \mathrm{Tg}$ or $0.5 \mu \mathrm{g} / \mathrm{ml} \mathrm{Tm}$ were added to cell and the luciferase assay was performed as described; luciferase activities were measured in three independent experiments.

RNA isolation and semiquantitative RT-PCR analysis. SK-N-SH cells or MEFs were washed with phosphate-buffered saline (PBS) and then collected by centrifugation. Total RNA was isolated from cells using an RNeasy kit (Qiagen, Tokyo, Japan) according to the manufacturer's protocol. Total RNA was isolated from frozen brains using the acid guanidine-phenol-chloroform RNA extraction method provided as ISOGEN (Nippon Gene, Toyama, Japan), and purified using an RNeasy Mini kit (Qiagen). RNA concentrations were determined spectrophotometrically at $260 \mathrm{~nm}$. First-strand cDNA was synthesized in a $20-\mu \mathrm{l}$ reaction volume using a random primer (Takara, Shiga, Japan) and Moloney murine leukemia virus reverse transcriptase (Invitrogen). PCR was performed in a total volume of $30 \mu \mathrm{l}$ containing $0.8 \mu \mathrm{M}$ of each primer, $0.2 \mathrm{mM}$ dNTPs, $3 \mathrm{U}$ Taq DNA polymerase (Promega), $2.5 \mathrm{mM} \mathrm{MgCl}$, and $1 \times$ PCR buffer. The amplification conditions for semiquantitative RT-PCR analysis were as follows: an initial denaturation step of $95^{\circ} \mathrm{C}$ for $5 \mathrm{~min}, 22$ cycles of $95^{\circ} \mathrm{C}$ for $1 \mathrm{~min}, 55^{\circ} \mathrm{C}$ for $1 \mathrm{~min}$, and $72^{\circ} \mathrm{C}$ for $1 \mathrm{~min}$, and a final extension step of $72^{\circ} \mathrm{C}$ for $7 \mathrm{~min}$. The numbers of amplification cycles for detection of $\mathrm{BiP}$ and $\beta$-actin were 18 and 15 , respectively. The primers used for amplification were as follows: BiP: $5^{\prime}$-GTTTGCTGAGG AAGACAAAAAGCTC- $3^{\prime}$ and 5' ${ }^{\prime}$-CACTTCCATAGAGTTTGCTGATAATTG-3'; XBP1: $5^{\prime}$-CAGCGCTTGGGGATGGATGC-3' ${ }^{\prime}$ and $5^{\prime}$-CCATGGGGAGATGTTCTG GA-3'; CHOP: $5^{\prime}$-GGAGCTGGAAGCCTGGTATGAGG-3' and 5'-TCCCTGGTCA GGCGCTCGATTTCC-3'; GRP94: 5' - CTCACCATTTGGATCCTGTGTG- $3^{\prime}$ and $5^{\prime}$ CACATGACAAGATTTTACATCAAGA-3'; calreticulin: 5'-GCCAAGGACGAGCT GTAGAGAG-3' and 5'-GGTGAGGGCTGAAGGAGAATC-3'; ERdj4/MDG1: $5^{\prime}$ TCTAGAATGGCTACTCCCCAGTCAATTTTC- $3^{\prime}$ and $5^{\prime}$-TCTAGACTACTGTCCT GAACAGTCAGTG-3'; EDEM: $5^{\prime}$-TGGGTTGGAAAGCAGAGTGGC- $3^{\prime}$ and $5^{\prime}$ TCCATTCCTACATGGAGGTAG-3'; $558^{\text {IPK }} 5^{\prime}$-GAGGTTTGTGTTTGGGATGCAG-3' and $5^{\prime}$-GCTCTTCAGCTGACTCAATCAG-3'; ASNS: $5^{\prime}$-AGGTTGATGATGCAATG ATGG-3' and $5^{\prime}$-TCCCCTATCTACCCACAGTCC-3'; $\beta$-actin: $5^{\prime}$-TCCTCCCTGGA GAAGAGCTAC- $3^{\prime}$ and $5^{\prime}$-TCCTGCTTGCTGATCCACAT- $3^{\prime}$. PCR products were resolved by electrophoresis through $4.8 \%$ (w/v) polyacrylamide gels. The density of each band was quantified using the Scion Image Program (Scion Corporation, Frederick, MD, USA).
Northern blot analysis. Total RNA ( $10 \mu \mathrm{g} / \mathrm{lane})$ was resolved by electrophoresis through $1.0 \%$ agarose/formaldehyde gels and transferred onto Immobilon-NY + membranes (Millipore, Bedford, MA, USA). Filters were hybridized with ${ }^{32} \mathrm{P}$-labeled cDNA probes generated from the BiP CDNA by the Random Primer DNA labeling kit (Takara). After washing in $2 \times \mathrm{SSC} / 0.1 \%$ SDS and $0.1 \times$ SSC/0.1\% SDS, filters were exposed onto IP plates (Fuji Film, Tokyo, Japan) and analyzed using a BAS1800 system (Fuji Film).

Real-time PCR. TaqMan real-time PCR was performed as described previously. ${ }^{24}$ Single-stranded cDNA was synthesized from total RNA using a High-Capacity cDNA Archive Kit (Applied Biosystems, Foster City, CA, USA). Quantitative real-time PCR was performed using an ABI PRISM ${ }^{\circledR} 7900 \mathrm{HT}$ Sequence Detection System (Applied Biosystems) with a TaqMan Universal PCR Master Mix (Applied Biosystems) according to the manufacturer's protocol. The expressions of mRNAs were measured by real-time PCR using the Applied Biosystems Assays-on-Demand ${ }^{\mathrm{TM}}$ Gene Expression Product. The thermal cycler conditions were as follows: $2 \mathrm{~min}$ at $50^{\circ} \mathrm{C}$ and then $10 \mathrm{~min}$ at $95^{\circ} \mathrm{C}$, followed by twostep PCR for 50 cycles consisting of $95^{\circ} \mathrm{C}$ for $15 \mathrm{~s}$ followed by $60^{\circ} \mathrm{C}$ for $1 \mathrm{~min}$. For each PCR, we checked the slope value, $R^{2}$ value, and linear range of a standard curve of serial dilutions. All reactions were performed in duplicate. The results are expressed relative to the $\beta$-actin, internal control.

Immunoblot analysis. Cells were washed with PBS, harvested and lysed in Nonidet P-40 lysis buffer ( $1 \%$ Nonidet P-40, 20 mM HEPES (pH 7.6), $100 \mathrm{mM} \mathrm{NaCl}$, $3 \mathrm{mM} \mathrm{MgCl}_{2}, 5 \mathrm{mM}$ dithiothreitol, and $0.1 \%$ protease inhibitor cocktail (Sigma)). Lysates were then sonicated on ice three times for $5 \mathrm{~s}$ and centrifuged at 15000 r.p.m. for $5 \mathrm{~min}$. Supernatants were retained and boiled for $5 \mathrm{~min}$ in SDS sample buffer. Equal amounts of protein were subjected to 10-15\% SDS-PAGE, transferred to PVDF membranes, and immunoblotted with each primary antibody. Membranes were washed with TBS/Tween-20, and then incubated with an alkaline phosphatase-conjugated secondary antibody (Sigma). The corresponding bands were detected using ECL Plus Western Blotting Detection System (GE Healthcare UK Ltd, Buckinghamshire, England). The density of each band was quantified using the Scion Image Program (Scion Corporation). As primary antibodies, anti-PERK antibody was provided by Dr. David Ron (New York University) and anti-IRE1 $\alpha$ antibody was provided by Dr. Fumihiko Urano (University of Massachusetts Medical School). Anti-KDEL (Stressgen, Victoria, BC, Canada), anti-total elF2 $\alpha$ (Cell signaling Technology, Beverly, MA, USA), anti-eIF2 $\alpha$ (phosphospecific) (Stressgen), anti-ATF6 $\alpha$ (Santa Cruz Biotechnology, Santa Cruz, CA, USA), antiATF6 $\beta$ (Santa Cruz Biotechnology), anti-TX (MBL Co. Ltd, Nagoya, Japan), and anti-actin (Chemicon, Temecula, CA, USA) antibodies were purchased commercially. Anti-KDEL antibody detected BiP and GRP94. Anti-TX antibody detected caspase 4 protein.

Caspase activity. SK-N-SH cells were seeded into 96 -well culture plates $\left(1.0 \times 10^{4}\right.$ cells/well). Cells were cultured under standard conditions for $12 \mathrm{~h}$, and then treated with $5 \mu \mathrm{M}$ BIX or vehicle for another $12 \mathrm{~h}$. After BIX or vehicle treatment, the whole medium was replaced with fresh medium containing $0.5 \mu \mathrm{g} / \mathrm{ml}$ $\mathrm{Tm}$ and cells were incubated for additional 36 or $48 \mathrm{~h}$. After incubation, caspase-3 and -7 activity was measured using a caspase-Glo 3/7 Assay kit (Promega), according to the manufacturer's instructions. Luminescent signals were measured using a luminometer (Berthold Technologies). The measurement of caspases 3 and 7 activities was conducted in three independent experiments.

Cell death assay. SK-N-SH cells were pretreated with $5 \mu \mathrm{M}$ BIX or vehicle for $12 \mathrm{~h}$, after which the whole medium was replaced with fresh medium containing $0.5 \mu \mathrm{g} / \mathrm{ml} \mathrm{Tm}$, in which cell were cultured for the indicated times. Cells were fixed with $4 \%$ paraformaldehyde for $30 \mathrm{~min}$ at $4{ }^{\circ} \mathrm{C}$, washed with PBS for $5 \mathrm{~min}$, and then stained with $100 \mu \mathrm{M}$ Hoechst 33258 (Wako Pure Chemical Co., Tokyo, Japan) in PBS for $20 \mathrm{~min}$. A total of 500 cells were counted randomly and apoptotic cells were determined by fluorescence microscopy.

Focal cerebral ischemia model in mice. Male adult ddY mice weighing $24-34 \mathrm{~g}$ (Japan SLC) were used in experiments, and were housed under diurnal lighting conditions. Anesthesia was induced by $2.0 \%$ isoflurane, then maintained using $1 \%$ isoflurane in $70 \% \mathrm{~N}_{2} \mathrm{O}$ and $30 \% \mathrm{O}_{2}$ using an animal general anesthesia machine (Soft Lander, Sin-ei Industry Co. Ltd, Saitama, Japan). Body temperature was maintained between 37.0 and $37.5^{\circ} \mathrm{C}$ with the aid of a heating pad and heating lamp. A filament occlusion of the left MCA was carried out as previously 
described. ${ }^{25,26}$ Briefly, the left MCA was occluded with an 8-0 nylon monofilament (Ethicon, Somerville, NJ, USA) coated with a mixture of silicone resin (Xantopren; Bayer Dental, Osaka, Japan). This coated filament was introduced into the internal carotid artery through the common carotid artery up to the origin of the anterior cerebral artery, so as to occlude the MCA and posterior communicating artery. At the same time, the left common carotid artery was occluded by the suture. Permanent ischemia was selected because it produced a reproducible subtotal infarction in our previous studies. ${ }^{25,26}$ Twenty-four hours after the occlusion, the forebrain was divided into five coronal $2 \mathrm{~mm}$ sections using a mouse brain matrix (RBM-2000C; Activational Systems, Warren, MI, USA). Sections were then stained with $2 \%$ TTC. Images of the infarcted areas were recorded using a digital camera (Nikon, COOLPIX4500), quantitated using Image J software (http://rsb.info.nih.gov/ $\mathrm{ij} /$ download/), and calculated as in a previous report. ${ }^{26}$ Brain swelling was calculated according to the following formula: (infarct volume + ipsilateral undamaged volume-contralateral volume $) \times 100 /$ contralateral volume $(\%) .{ }^{25}$ BIX was dissolved in $10 \%$ DMSO and fresh solution was made daily. DMSO $(10 \%)$ was used as a control. Physiologic parameters were recorded according to our previously described method. ${ }^{25}$ In brief, a polyethylene catheter was inserted into the femoral artery to sample arterial blood $(30 \mu \mathrm{l})$ and measure blood pressure. After the catheter had been inserted into the femoral artery, $2 \mu \mathrm{l}$ of BIX at 2.5 or $10 \mu \mathrm{g} / \mu \mathrm{l}$ was intracerebroventricularly administered $30 \mathrm{~min}$ before the start of the ischemia, because we do not know the permeability of $\mathrm{BIX}$ to the blood brain barrier. Body temperature, arterial blood pressure, $\mathrm{pO}_{2}, p \mathrm{pO}_{2}, \mathrm{pH}$, and plasma glucose were measured $15 \mathrm{~min}$ after the start of the ischemia. There were no significant differences in physiological parameters between the vehicle- and BIX-treated groups (data not shown). After $30 \mathrm{~min}$ of ischemia, vehicle- and BIX-treated mice exhibited moderate neurological deficits (such as circling, decreased resistance to lateral pushing, decreased locomotor activity, flexion of the right (contralateral to the ischemia) torso and forelimb upon lifting the animal by its tail, and abnormal posture). Animals showing no neurological deficits at $30 \mathrm{~min}$ after the occlusion were removed from the study on the grounds that they had not undergone successful occlusion of the MCA. We removed 2 out of 15 , 1 out of 13 , and 1 out of 13 mice in control, $5 \mu \mathrm{g} \mathrm{BIX-treated,} \mathrm{and} 20 \mu \mathrm{g}$ BIX-treated groups, respectively. The present experiments were performed in accordance with the Guidelines for Animal Experiments of Gifu Pharmaceutical University.

Neurological deficits. Mice were tested for neurological deficits at $24 \mathrm{~h}$ after MCA occlusion and scored as described previously ${ }^{25}$ using the following scale: $0=$ no observable neurological deficits (normal); $1=$ failure to extend the right forepaw (mild); 2 = circling to the contralateral side (moderate); $3=$ loss of walking or righting reflex (severe). The investigator who rated the mice was blinded as to the group to which each mouse belonged.

Immunohistochemistry. At $24 \mathrm{~h}$ after MCA occlusion, mice were injected with sodium pentobarbital (nembutal; $50 \mathrm{mg} / \mathrm{kg}$, i.p.), and then perfused through the left ventricle with $4 \%$ paraformaldehyde in $0.1 \mathrm{M}$ phosphate buffer (PB; $\mathrm{pH} 7.4$ ). Brains were removed after $15 \mathrm{~min}$ of perfusion fixation at $4^{\circ} \mathrm{C}$ and immersed in the same fixative solution overnight at $4^{\circ} \mathrm{C}$. They were then immersed in $25 \%$ sucrose in $0.1 \mathrm{M} \mathrm{PB}$ for $24 \mathrm{~h}$, and finally frozen in powdered dry ice. Coronal sections $(10 \mu \mathrm{m})$ were cut on a cryostat at $-20^{\circ} \mathrm{C}$ and stored at $-80^{\circ} \mathrm{C}$ until use. After rehydration, endogenous peroxidase activity was quenched using $1 \%$ hydrogen peroxidase in methanol. Next, brain sections were blocked with $3 \%$ BSA in PBS/0.1\% Triton $\mathrm{X}-100$ for $1 \mathrm{~h}$, and then incubated overnight at $4^{\circ} \mathrm{C}$ with primary antibody in the same buffer. Sections were washed and then incubated with biotinylated secondary antibody before being incubated for $30 \mathrm{~min}$ at room temperature with avidin-biotinperoxidase complex, and then developed using diaminobenzidine (DAB) peroxidase substrate. Caspase 3 -stained cells were counted in the striatum. The results are expressed as positive cells per $1 \mathrm{~mm}^{2}$.

TUNEL staining. Apoptosis was detected using the TUNEL method using an in situ cell death detection kit, POD (Roche, Penzberg, Germany). TUNEL signals were developed using a DAB peroxidase substrate kit (Vector Labs, Burlingame, CA, USA).

In situ hybridization histochemistry. CHOP and GAPDH cDNAs were subcloned into pGEM-T Easy and pBluescript vectors, respectively. Digoxigeninlabeled CRNA probes were made by in vitro transcription in the presence of digoxigenin using subcloned cDNAs for these genes as templates. In situ hybridization using digoxigenin-labeled cRNA probes was performed as previously described. $^{27}$

Statistical analysis. Statistical comparisons were made using a one-way ANOVA followed by a Student's t-test, Dunnett's test, or the Mann-Whitney U-test. STATVIEW version 5.0 (SAS Institute Inc., Cary, NC, USA) was used for statistical analyses. $P<0.05$ was considered to indicate statistical significance.

Acknowledgements. We thank Dr. David Ron for the PERK ${ }^{-1-}$ MEFs and the anti-PERK antibody, Dr. Fumihiko Urano for the IRE1 ${ }^{-1-}$ MEFs and the antiIRE1 $\alpha$ antibody, Dr. Laurie H Glimcher for the iATF6 $\alpha \beta$ MEFs, and Dr. K Mori for the BiP-pGL3 reporter plasmid. We also thank Ms Mikiko Kubo for her technical assistance. This work was supported by a Grant-in-Aid for Scientific Research (17200026) from the Japan Society for the Promotion of Science and Research on Psychiatric and Neurological Diseases and Mental Health from the Japan Ministry of Health, Labor, and Welfare. This study was supported by the Program for Promotion of Fundamental Studies in Health Sciences of the National Institute of Biomedical Innovation. Funding was also provided by the Japan Society for the Promotion of Science (SK).

1. Zhang K, Kaufman RJ. The unfolded protein response: a stress signaling pathway critical for health and disease. Neurology 2006; 66 (Suppl 1): s102-s109.

2. Katayama T, Imaizumi K, Sato N, Miyoshi K, Kudo T, Hitomi J et al. Presenilin-1 mutations downregulate the signalling pathway of the unfolded-protein response. Nat Cell Biol 1999; 8: $479-485$.

3. Katayama T, Imaizumi K, Honda A, Yoneda T, Kudo T, Takeda M et al. Disturbed activation of endoplasmic reticulum stress transducers by familial Alzheimer's diseaselinked presenilin 1 mutations. J Biol Chem 2001; 276: 43446-43454.

4. Yasuda Y, Kudo T, Katayama T, Imaizumi K, Yatera M, Okochi M et al. FAD-linked presenilin-1 mutants impede translation regulation under ER stress. Biochem Biophys Res Commun 2002; 296: 313-318.

5. Hitomi J, Katayama T, Eguchi $Y$, Kudo T, Taniguchi M, Koyama $Y$ et al. Involvement of caspase- 4 in endoplasmic reticulum stress-induced apoptosis and $A \beta$-induced cell death. J Cell Biol 2004; 165: 347-356.

6. Kitada T, Asakawa S, Hattori N, Matsumine H, Yamamura Y, Minoshima S et al. Mutations in the Parkin gene cause autosomal recessive juvenile Parkinsonism. Nature 1998; 392: 605-608.

7. Imai $Y$, Soda M, Inoue $H$, Hattori N, Mizuno $Y$, Takahashi R. An unfolded putative transmembrane polypeptide, which can lead to endoplasmic reticulum stress, is a substrate of Parkin. Cell 2001; 105: 891-902.

8. Nishitoh H, Matsuzawa A, Tobiume K, Saegusa K, Takeda K, Hori S et al. ASK1 is essential for endoplasmic reticulum stress-induced neuronal cell death triggered by expanded polyglutamine repeats. Gene Dev 2002; 16: 1345-1355.

9. Bence NF, Sampat RM, Kopito RR. Impairment of the ubiquitin-proteasome system by protein aggregation. Science 2001; 292: 1552-1555.

10. Kumar R, Azam S, Sullivan JM, Owen C, Cavener DR, Zhang P et al. Brain ischemia and reperfusion activates the eukaryotic initiation factor 2alpha kinase, PERK. $J$ Neurochem 2001; 77: 1418-1421.

11. Paschen W, Aufenberg $C$, Hotop S, Mengesdorf T. Transient cerebral ischemia activates processing of xbp1 messenger RNA indicative of endoplasmic reticulum stress. J Cereb Blood Flow Metab 2003; 23: 449-461.

12. Boyce M, Bryant KF, Jousse $C$, Long K, Harding HP, Scheuner $D$ et al. A selective inhibitor of elF2 $\alpha$ dephosphorylation protects cells from ER stress. Science 2005; 307: 935-939.

13. Kim AJ, Shi Y, Austin RC, Werstuck GH. Valproate protects cells from ER stress-induced lipid accumulation and apoptosis by inhibiting glycogen synthase kinase-3. J Cell Sci 2005; 118: 89-99.

14. ZaiFang $Y$, Luo $H$, Weiming F, Mattson MP. The endoplasmic reticulum stress-responsive protein GRP78 protects neurons against excitotoxicity and apotosis: suppression of oxidative stress and stabilization of calcium homeostasis. Exp Neurol 1999; 155: 302-314.

15. Rao RV, Peel A, Logvinova A, del Rio G, Hermel E, Yokota T et al. Coupling endoplasmic reticulum stress to the cell death program: role of the ER chaperone GRP78. FEBS Lett 2002; 514: 122-128.

16. Reddy RK, Mao C, Baumeister P, Austin RC, Kaufman RJ, Lee AS. Endoplasmic reticulum chaperone protein GRP78 protects cells from apoptosis induced by topoisomerase inhibitors: role of ATP binding site in suppression of caspase-7 activation. J Biol Chem 2003; 278: 20915-20924.

17. Gomer C, Ferrario A, Rucker N, Wong S, Lee AS. Glucose regulated protein induction and cellular resistance to oxidative stress mediated by porphyrin photosensitization. Cancer Res 1991; 51: 6574-6579.

18. Li LJ, Li X, Ferrario A, Rucker N, Liu ES, Wong S et al. Establishment of a Chinese hamster ovary cell line that expresses grp78 antisense transcripts and suppresses A23187 induction of both GRP78 and GRP94. J Cell Physiol 1992; 153: 575-582. 
19. Sugawara S, Takeda K, Lee A, Dennert G. Suppression of stress protein GRP78 induction in tumor B/C10ME eliminates resistance to cell mediated cytotoxicity. Cancer Res 1993 53: $6001-6005$

20. DeGracia DJ, Montie HL. Cerebral ischemia and the unfolded protein response. $J$ Neurochem 2004; 91: 1-8.

21. Kaufman RJ. Orchestrating the unfolded protein response in health and disease. J Clin Invest 2002; 110: 1389-1398.

22. Tajiri S, Oyadomari S, Yano S, Morioka M, Gotoh T, Hamada Jl et al. Ischemia-induced neuronal cell death is mediated by the endoplasmic reticulum stress pathway involving CHOP. Cell Death Differ 2004; 11: 403-415.

23. Bertolotti A, Zhang Y, Hendershot LM, Harding HP, Ron D. Dynamic interaction of BiP and ER stress transducers in the unfolded-protein. Nat Cell Biol 2000; 2: 326-332.
24. Chen D, Padiernos E, Ding F, Lossos IS, Lopez CD. Apoptosis-stimulating protein of p53-2 (ASPP2 ${ }^{53 \mathrm{BP} 2 \mathrm{~L}}$ ) is an E2F target gene. Cell Death Differ 2005; 12: 358-368.

25. Hara H, Huang PL, Panahian N, Fishman MC, Moskowitz MA. Reduced brain edema and infarction volume in mice lacking the neuronal isoform of nitric oxide synthase after transient MCA occlusion. J Cereb Blood Flow Metab 1996; 16: 605-611.

26. Hara H, Friedlander RM, Gagliardini V, Ayata C, Fink K, Huang Z et al. Inhibition of interleukin $1 \beta$ converting enzyme family proteases reduces ischemic and excitotoxic neuronal damage. Proc Natl Acad Sci USA 1997; 94: 2007-2012.

27. Honma $\mathrm{Y}$, Kanazawa $\mathrm{K}$, Mori T, Tanno $\mathrm{Y}$, Tojo M, Kiyosawa $\mathrm{H}$ et al. Identification of a novel gene, OASIS, which encodes for a putative CREB/ATF family transcription factor in the long-term cultured astrocytes and gliotic tissue. Brain Res Mol Brain Res 1999; 69: 93-103. 